\title{
Dwa fragmenty poświęcone etyce
}

\author{
O etyce w ogólności
}

1. Szczęście i nieszczęście to dwie potężne motywacje ludzkich działań i choć ludzie podążają rozmaitymi ścieżkami, widzimy, że w swych różnych zajęciach zawsze mają na względzie szczęście i unikanie nieszczęścia, które objawia im się w rozmaitych miejscach i formach ${ }^{1}$.

${ }^{1}$ Pierwszy z publikowanych tu fragmentów stanowi szkic do jednego z rozdziałów Rozważań dotyczacych rozumu ludzkiego, na co wskazuje chociażby fakt, że jeden z akapitów znajdujemy w Szkicu B do tego dzieła (Drafts for the 'Essay Concerning Human Understanding' and Other Philosophical Writings, ed. P. H. Nidditch, G. A. J. Rogers, vol. I, Clarendon Press, Oxford 1990, s. 169-170). Także krytyka stanowiska Arystotelesa, wskazanie na różnorodność norm moralnych panujących u różnych ludów jako przesłanki konieczności poszukiwania jednego racjonalnego prawa natury, a także określenie terminów moralnych jako złożonych idei modi, wpisują ów fragment w całość Rozważań. Wydawca pism Locke’a W. von Leyden datuje powstanie tego tekstu ok. 1687 roku, czyli pod koniec wymuszonego sytuacją polityczną pobytu Locke'a w Holandii, gdzie filozof dokonał jego ostatecznej redakcji (W. von Leyden, Introduction, [w:] J. Locke, Essays on the Law of Nature, ed. W. von Leyden, Clarendon Press, Oxford 1970, s. 69). Zdaniem J. C. Higgins-Biddle’a tekst O etyce w ogólności miał wejść do czwartej księgi Rozważań, jako rozdział XVII (Introduction, [w:] J. Locke, The Reasonableness of Christianity, ed. J. C. Higgins-Biddle, Clarendon Press, Oxford 2000, s. XCVIII). Tak się jednak nie stało: rozwinięcie podjętej w tym fragmencie tematyki zapewne nie mieściło się zdaniem Locke’a w ramach Rozważań, częściowo też zostało przezeń zawarte w Drugim traktacie. Ponieważ Szkic B powstał w 1671 roku, a Rozważania zostały opublikowane na przełomie lat 
2. Nie przypominam sobie, iżbym słyszał, aby jakiś lud nie uznawał, że ludzkie poczynania mogą być słuszne bądź niesłuszne, podobnie jak to, co się mówi, może być prawdziwe bądź fałszywe. Wszędzie przyznaje się, że ludzkie

1689/1690, fragment ten daje sposobność dostrzeżenia długotrwałych wysiłków Locke’a zmierzających do zapewnienia tematycznej spójności najważniejszemu dziełu. Drugi fragment jest nieco późniejszy; umieszczona w nagłówku liczba „92” wskazuje na rok 1692, co zgadza się ze zwyczajem, wedle którego Locke datował wpisy w swych notatnikach.

Warto zauważyć, że pod względem treści fragmenty te wpisują się w tematykę zarówno wczesnych, pochodzących z początku lat 1660. Questions Concerning the Law of Nature, jak i dzieł wydanych w później - Rozważań oraz Drugiego traktatu o rządzie. Jeśli chodzi o możliwość dowodzenia istnienia Boga, w Questions Locke odwoływał się do argumentu fizyko-teologicznego; pisał tam na temat prawa natury: „podstawa wszelkiej wiedzy o nim pochodzi od rzeczy poznawanych za pomocą zmysłów. Od nich to rozpoczynając, rozum nasz, czyli właściwa człowiekowi zdolność dowodzenia za pomocą twierdzeń koniecznych na temat materii, ruchu i widzialnej konstytucji świata i jego budowy przechodzi do twórcy owych rzeczy, by na koniec dojść do wniosku i ustalić jako pewnik, że istnieje pewien Bóg, będący wszystkich tych rzeczy stwórcą" (J. Locke. Questions Concerning the Law of Nature, translated and edited by R. Horwitz, J. Strauss Clay, D. Clay, Cornel University Press, Ithaca - London 1990, s. 131-133). W Rozważaniach Locke argument ten zarzuca na rzecz dowodu z przyczynowości (ks. IV, rozdz. X, par. 1-6; przeł. B. Gawecki, Warszawa 1955, t. 2, s. 336-339), natomiast w Drugim traktacie rozwija przedstawioną zarówno w Questions, jak i w O etyce w ogólności koncepcję Stwórcy jako prawodawcy gwarantującego powszechność obowiązywania prawa natury: „Ludzie, będąc stworzeni przez jednego, wszechmogącego i nieskończenie mądrego Stwórcę, są wszyscy sługami jednego, suwerennego Pana, zostali przysłani na świat z Jego rozkazu i na jego polecenie, są jego własnością, Jego dziełem, zostali stworzeni, by istnieć tak długo, jak Jemu, a nie komukolwiek innemu będzie się podobać. [...] Prawo natury, jak wszystkie inne prawa, które dotyczą człowieka na tym świecie, istniałoby na próżno, gdyby nie było nikogo, kto w stanie natury nie posiadałby władzy jego wykonywania, a tym samym ochrony niewinnych i powściągania przestępców" (J. Locke, Drugi traktat o rządzie, par. 6-7, przeł. Z. Rau, PWN, Warszawa 1990, s. 166-167). Idea Boga-prawodawcy łączy prawnonaturalną koncepcję moralną i polityczną Locke’a (z prawa natury można wywieść inne obowiązki człowieka) z jego teorią teologiczną przedstawioną w The Reasonableness of Christianity (dotyczącą stosunku religii naturalnej do Objawienia, podkreślenia roli Chrystusa jako Mesjasza, co jako podstawowa prawda religii objawionej miało godzić zwaśnione odłamy protestantyzmu, to zaś z kolei wiodło do zasad tolerancji wyznaniowej). Z podejmowaną przez Locke’a problematyką teologiczną wiąże się również hedonistyczne i eudajmonistyczne pojmowanie etyki. Chodzi tu nie tylko o przeciwstawienie wyższych (zmysłowych) i niższych (rozumowych) przyjemności, lecz także o stwierdzenie, że celem postępowania człowieka jest przyjemność i szczęście, co wiąże się u Locke’a także z wizją zmartwychwstania ludzkich ciał oraz udzielonej zbawionym wiecznej przyjemności po Sądzie Ostatecznym (J. Locke, Resurrectio et quae secuuntur, [w:] tenże, Writings on Religion, s. 233).

Chociaż zagadnieniom ściśle etycznym Locke nie poświęca zbyt wiele miejsca w swych pracach, należy dodać, że uwagi o wynikającym z podległości Stwórcy prawie moralnym 
działania podlegają pewnym kryteriom, choćby nawet reguły i ograniczenia, wedle których ludzkie postępki ocenia się jako dobre bądź złe, były różne; sądzę również, że nie istnieje lud ludzki, który nie zna różnicy pomiędzy cnotą i występkiem. Można dostrzec, że wszędzie przyjmuje się taką czy inną moralność, nie twierdzę, że doskonałą czy dokładną, lecz przecież wystarczającą, abyśmy mogli stwierdzić, że jej pojęcie znane jest ogólnie rzecz biorąc wszędzie, i że nawet tam, gdzie brak głosu społeczności politycznej czy urzędów, ludzie podlegają pewnym prawom i winni są im posłuszeństwo.

3. Chociaż jednak moralność jest przedmiotem wielkiej ludzkiej uwagi i starań, a przez to zasługuje na to, aby badaniu jej poświęcić się z największym oddaniem, już na samym wstępie dostrzegamy rzecz wielce dziwną i zasługującą na rozważenie, mianowicie to, że na ogół etykę [Morality $]^{2}$ traktowano jako naukę [science] odrębną od teologii, religii i prawa, dziedzinę właściwą filozofom, ci zaś tym różnią się od kapłanów i prawników, że ci drudzy zajmują się wyjaśnianiem światu owej wiedzy oraz pouczaniem go. Jest dla mnie jasne, że ci, który zajmują się prawem natury, muszą odnaleźć pewną ukrytą regułę postępowania, której przestrzeganie leży w interesie istot rozumnych. Różni się ona od tego, co kapłan uznaje za bezpośredni Boży nakaz (gdyż rytuały w pogańskich kultach także odwoływały się do objawienia, którego rozum nie jest w stanie uzasadnić), a także od tego, co prawnik ogłasza jako urzędowy nakaz.

4. A przecież filozofowie ci rzadko kiedy wywodzili owe zasady z ich źródła i twierdzili, że są one nakazami Boga, wielkiego władcy nieba i ziemi, wedle których ludzie zostaną wynagrodzeni w przyszłym życiu. Aby nadać owym regułom moc obowiązywania, mogli oni co najwyżej określić je mia-

zostają w Rozważaniach rozwinięte i uzupełnione. Locke wyróżnia tam trzy rodzaje praw normujących ludzkie postępowanie: prawo boskie, prawo państwowe i prawo opinii, czyli reputacji: „Zestawiając swe działania z prawem pierwszego rodzaju, ludzie rozstrzygają, czy ich uczynki są grzeszne, czy zgodne z obowiązkiem; zestawiając z drugim - czy są karalne, czy legalne; z trzecim - czy są cnotliwe, czy występne" (Rozważania, ks. II, rozdz. 28, par. 7, wyd. polskie: t. 1, s. 499). Prawa te nie muszą różnić się treścią, odmienny jest natomiast sposób ich uzasadniania i zakres obowiązywania, przy czym tylko pierwsze z nich ma charakter bezwzględny.

Podstawa przekładu: J. Locke, Of Ethick in General, Ethica, [w:] tenże, Writings on Religion, ed. Victor Nuovo, Clarendon Press, Oxford 2002, s. 9-16. Przypisy pochodzą od tłumaczy.

${ }^{2}$ Oddajemy oryginalny termin morality jako „etyka”, ponieważ jest tu mowa o „dziedzinie właściwej filozofom”, a rodzimy termin „moralność” ma już odmienne ugruntowane znaczenie, bliskie „obyczajności”. 
nem cnót i przywar³ , co miało ściągnąć na kogoś szacunek bądź hańbę. Czynili to jedynie mocą swego autorytetu, który pozwalał im na ocenianie swych uczniów i reszty ludzi. Jednak nawet gdyby nie było ustanowionego przez ludzi prawa $z$ karami przewidzianymi przez obywatelskie czy religijne wymogi, wciąż jeszcze istniałyby na świecie takie rodzaje postępków, jak sprawiedliwość, powściągliwość, męstwo, pijaństwo i kradzież, wciąż jeszcze niektóre z nich uznawano by za dobre, inne za złe, wciąż jeszcze odróżniano by też pojęcia cnoty i występku. Każdemu $\mathrm{z}$ tych pojęć towarzyszą pewne złożone idee, gdyż w przeciwnym wypadku te i podobne im słowa, które we wszystkich językach wyrażają terminy moralne, byłyby pustymi i pozbawionymi znaczenia dźwiękami, wszelkie zaś rozprawy moralne byłyby zupełnym bełkotem. Cała wiedza na temat cnoty i występku, jaką ludzie mogą w ten sposób osiągnąć, nie byłaby jednak czymkolwiek więcej niż przyjęciem definicji, czyli znaczenia, jakie słowa te mają w każdym języku; pochodziłyby one albo od tych, którzy są bardziej wprawieni w jego posługiwaniu, albo z potocznego znaczenia, jakie mają one w danym kraju, które to znaczenie pozwala stwierdzić, $w$ jaki sposób stosować te pojęcia i jakimi odpowiednimi nazwami określać poszczególne uczynki. W związku z tym wiedza ta sprowadzałaby się jedynie do umiejętności odpowiedniego posługiwania się językiem, a w najlepszym wypadku do tego, że ktoś poznałby, jakie postępki w kraju, w którym żyje, uważa się za godne pochwały bądź potępienia i określa mianem cnotliwych bądź występnych. W tym przypadku najpewniejszą

${ }^{3}$ Proponujemy przyjąć oddawanie terminu vice przede wszystkim jako „występek”. Przeciwieństwem „cnoty” jako dyspozycji charakteru moralnego jest jednak „przywara”, oddawana niekiedy jako „wada”, jak w tłumaczeniu przypisywanego Arystotelesowi traktatu Пepì

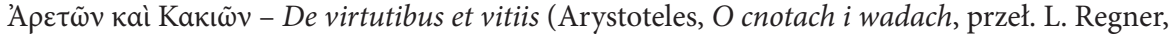
[w:] tenże, Dzieła wszystkie, t. 5, PWN, Warszawa 1996, s. 496-505). Skłonni bylibyśmy jednak używać terminu „przywara” z trzech powodów. Pierwszy to ten, że ów częściowo anachroniczny termin jest utarty przez wpływ tłumaczenia Tadeusza Boya-Żeleńskiego Prób Michela de Montaigne, a stamtąd przeszedł bezpośrednio do tytułu pracy Judith Shklar Zwyczajne przywary (zob. J. Shklar, Zwyczajne przywary, przeł. M. Król, Społeczny Instytut Wydawniczy Znak, Kraków 1997, s. 9, przyp. 1). Drugi to ten, że termin „wada” zyskał dziśs szersze znaczenie i przez to częściowo uniezależnił się od kontekstu etycznego. Wreszcie trzeci powód wiąże się ze stopniowym wychodzeniem $\mathrm{z}$ użycia terminu „przywara” $\mathrm{w}$ języku potocznym, o które jednak chcemy się upomnieć, zwłaszcza w kontekście tłumaczenia tekstu historycznego. Ponieważ jednak Locke nie rozwija w tekście odrębnej koncepcji charakteru moralnego i związanej z nim teorii cnoty, tam gdzie mowa jest o prostej opozycji dobrego i złego czynu, posługuje się raczej potocznym rozumieniem opozycji virtue \& vice, dlatego też pojęcia te najczęściej oddajemy jako „cnotę” i „występek”. 
zasadą, jaką mógłbym znaleźć, jest to, że za cnotliwe postępki uznaje się te, które uważa się za koniecznie potrzebne do zachowania społeczności, a te, które psują lub niszczą więzi łączące społeczność, zawsze uważa się za złe i występne.

5. To właśnie musi się zdarzyć, jeśli bowiem nie istniałby żaden inny nakaz lub wyższe prawo poza tym, które służy społeczności, trudno byłoby założyć, że jacyś ludzie zrzeszyliby się i zjednoczyli w tej samej społeczności, a jednocześnie traktowali jako karygodne, tj. uważali za przywary, te postępki, które prowadzą do rozkładu jednoczącej ich społeczności, a zarazem wszelkie inne uczynki, które nie mają tak szkodliwego wpływu na społeczeństwo, uznawaliby za chwalebne, a więc cnotliwe - na ile jestem obeznany $z$ historiami, tak jednak się nie zdarza: same postępki, które w niektórych krajach czy społecznościach uważa się za cnotliwe, w innych traktuje się jako przywary, a jeszcze gdzie indziej jako czyny całkowicie obojętne. Zależy to od tego, czy gorszą one ludzi sprawujących urzędy, albo od tego, czy panujące nastroje bądź opinie czyny te przypadkiem uznały za cnotliwe bądź występne. Tak przyjmowane idee cnoty nie pouczają nas o niczym innym, jak tylko o tym, w jaki sposób poprawnie wyrażać się, zależnie od opinii panujących w kraju, w którym aktualnie się znajdujemy. W ten sposób nie wiemy wiele więcej ponad to, jakie znaczenie ludzie nadają takim słowom, taka zaś wiedza dotyczy jedynie potocznej etyki [tradycyjnych] szkół [common Ethics of the Schools]: chodzi w niej jedynie o to, aby znać odpowiednie nazwy modi złożonych i umieć się odpowiednio wysławiać.

6. Etyka szkół oparta na autorytecie Arystotelesa wprowadziła jedynie jeszcze większe zamieszanie swymi sztywnymi słowami i bezużytecznymi rozróżnieniami, które mówią nam o tym, co Arystoteles lub przedstawiciele szkół zechcieli nazywać cnotami lub przywarami, przez co nie nauczyli nas oni niczego na temat moralności, a jedynie pozwolili nam zrozumieć nadane przez siebie nazwy i określać postępki tak samo jak Arystoteles, co nie prowadzi do niczego innego, jak tylko do poprawnego posługiwania się jego językiem. Ponieważ celem etyki [Morals] oraz płynącym z niej pożytkiem jest kierowanie naszym życiem i ukazywanie nam, które postępki są dobre, które zaś złe oraz sprawienie, abyśmy jedne z nich czynili, drugich zaś unikali, ci, którzy twierdzą, że nauczają w ten sposób moralności, mylą się; są oni jedynie mistrzami w posługiwaniu się językiem. Nie nauczają oni etyki, gdy uczą nas jedynie rozprawiać i prowadzić dysputy, nadawać uznane przez siebie nazwy ludzkim postępkom, nie wskazują jednak, jak przywieść nas do cnoty i odwieść od występku. 
7. Postępkami moralnymi są jedynie te, które wynikają z decyzji istoty rozumnej i wolnej [choise of an understanding and free agent], natomiast ktoś, kto jest rozumny i wolny, w naturalny sposób dąży do tego, co daje mu przyjemność, stroni zaś od tego, co jest przyczyną przykrości, to jest w sposób naturalny pragnie szczęścia i unika nieszczęścia. To, co sprawia mu przykrość, jest dlań złe; to, co sprawia mu większą przyjemność, jest dlań większym dobrem, to zaś, co sprawia mu większą przykrość, jest większym dlań złem. Ponieważ zgodnie ze znaczeniem słów szczęście i nieszczęście [happynesse \& misery], które podałem powyżej (L. 2 c 21), polegają one jedynie na przyjemności i przykrości umysłu lub ciała albo obu ich łącznie, nic nie może być dla nikogo dobre bądź złe, jeśli nie przyczynia się do jego szczęścia bądź nieszczęścia, dając mu przyjemność bądź przykrość. Ponieważ dobro i zło są terminami względnymi, nieodnoszącymi się do niczego, co tkwi w samej istocie rzeczy, a jedynie do stosunku, w jakim pozostają do kogoś, gdy mogą stać się dlań przyczyną przyjemności bądź przykrości. Widzimy przeto i twierdzimy, że to, co dla kogoś jest dobrem, dla drugiego jest złem.

8. Tak więc choć zazwyczaj tego się nie twierdzi, to jednak owa tendencja do wytwarzania $\mathrm{w}$ nas przyjemności bądź przykrości jest podstawą określenia moralnego oraz naturalnego dobra i zła. Dlatego też, choć może się to wydawać na pierwszy rzut oka czymś dziwnym, nie będzie błądził ktoś, kto stwierdzi, że rzeczą moralnie dobrą nie może być taka, która nie daje komuś przyjemności, natomiast rzeczą moralnie złą nie jest taka, która nie wiąże się z czyjąś przykrościąa ${ }^{4}$ Różnica pomiędzy moralnym a naturalnym dobrem i złem polega jedynie na tym, że jako naturalnie dobre bądź złe określamy te rzeczy, które stanowią naturalną przyczynę przyjemności bądź przykrości, podczas gdy dobre i złe moralnie jest to, co daje przyjemność i przykrość

${ }^{4} \mathrm{~W}$ tym miejscu w tekście znajduje się wykreślony następujący fragment: „Dlaczego jeden człowiek spłaca drugiemu dług, choć wolałby przeznaczyć pieniądze na swe własne wygody i potrzeby? Albo dlaczego inny nie nastaje na żonę swego sąsiada? Odpowie się zapewne: dlatego, iż jeden czyn cechuje moralna prawość i dobroć, zaś drugi moralna niegodziwość i podłość. Znakomite słowa. Ta moralna prawość, którą namysł każe uznać za zgodność z naturalnym prawem ogłoszonym przez Boga, nie znaczyłaby wówczas nic i tak naprawdę brakowało by powodu, abym w swych działaniach miał kierować się dobrem moralnym, gdyby nie było przyjemności, która łączyłaby się z nimi lub gdyby nie prowadziły do zmniejszenia przykrości. Gdyby jednak nie istniała przyjemność ani przykrość, które towarzyszyłyby zaspokajaniu przez kogoś pragnień na tyle, na ile jest to w jego mocy, czyż nie byłby głupcem ten, kto znosiłby przykrość głodu, mogąc w stodole i oborze swego sąsiada znaleźć wszystko, co potrzebuje, a jedynym złem, jakie płynęłoby z tego, że wziąłby to, co do niego nie należy, byłoby niebezpieczeństwo przejedzenia się." 
za sprawą istoty rozumnej, która ma możność sprawiania komuś przyjemności bądź przykrości, jeśli owa przyjemność bądź przykrość powstała nie jako skutek naturalny, ale wskutek mocy owej istoty. Tak zatem nadmierne upijanie się, gdy powoduje ból głowy i mdłości, jest złem naturalnym, ale gdy stanowi przekroczenie prawa, z czym wiąże się kara, stanowi zło moralne. Nagrody wiążą się z dobrem, kary zaś ze złem, za ich pomocą nasi zwierzchnicy wymuszają posłuszeństwo względem ustanowionych przez siebie praw, gdyż jest niemożliwe stworzenie jakiejś innej pobudki lub hamulca dla działań istoty wolnej i rozumnej, jak tylko wzgląd na dobro i zło, tj. przyjemność i przykrość, które wiążą się z takimi postępkami.

9. Ten, kto zajmuje się etyką [morality] o tyle tylko, że daje nam jedynie definicje sprawiedliwości i umiarkowania, kradzieży oraz braku opanowania i in., i powiada, które z nich należą do cnót, które zaś do przywar, ten jedynie łączy pewne złożone idee modi $\mathrm{z}$ ich nazwami, dzięki czemu możemy nauczyć się właściwie rozumieć innych, gdy mówią w zgodzie z regułami [swego języka], a także mówić rozumnie i w odpowiedni sposób do osób, które zaznajomiono $\mathrm{z}$ ich doktryną. Ponieważ jednak nigdy nie określają oni dokładnie, czym jest powściągliwość lub sprawiedliwość i nie wskazują na żadne prawo jakiegoś zwierzchnika, nakazujące kierować się umiarkowaniem lub zakazujące łamania tego prawa, które pociąga za sobą nagrody i kary, taka etyka traci całą swą moc i ulatnia się, zamieniając się w słowa, dysputy i zbędne subtelności. I choćby Arystoteles, Anacharsis, Konfucjusz, a także wielu innych spośród nas nazywali taki czy inny postępek cnotą bądź przywarą, ich autorytet jest zawsze podobny; ćwiczą się oni jedynie w tej samej zdolności, którą posiadają wszyscy: wskazują, jaką złożoną ideę oznaczają używane przez nich słowa. Albowiem bez ukazania prawa, które nakazuje bądź zakazuje ich, dobro moralne będzie jedynie pustym dźwiękiem, a te postępki, które ${ }^{5}$ szkoły nazwały cnotami lub przywarami, za sprawą czyjegoś autorytetu mogą $\mathrm{w}$ innym kraju uzyskać miano przeciwne. Jeśli chodziłoby w tym przypadku o czyjąś decyzję i postanowienie, wówczas w swych decyzjach ów człowiek będzie zobligowany do ich przestrzegania, a jego uczynki będą całkowicie obojętne.

10. Istnieje jednak jeszcze jeden rodzaj etyki, czyli reguł naszego postępowania, który choć w wielu miejscach może łączyć się z wcześniejszym i zgadzać się z nim, ma jednak inne podstawy, a do ich znajomości dochodzimy w odmienny sposób. Owe pojęcia i kryteria naszych postępków nie są wy-

\footnotetext{
${ }^{5}$ W tym miejscu skreślone: „Arystoteles”.
} 
tworem nas samych, którzy nadajemy im nazwy, lecz zależą od czegoś niezależnego od nas, a więc są stworzone nie przez nas, lecz dla nas; są to reguły naszego postępowania, stanowiące obwieszczoną nam wolę kogoś, w czyjej mocy jest karanie naszych od nich odstępstw. To one są rzeczywistą i prawdziwą miarą dobra i zła, ponieważ zgodność bądź niezgodność naszych działań z owymi regułami sprowadza na nas dobro albo zło, które mają wpływ na nasze życie, podobnie jak wcześniej wspomniane reguły wpływają na posługiwanie się przez nas słowami. Pomiędzy jednymi i drugimi regułami istnieje wielka różnica; w jednych chodzi o dobre życie i osiągnięcie szczęścia, $\mathrm{w}$ drugich o poprawne wyrażanie się i rozumienie słów. O pierwszych ludzie zdobywają pojęcie, gdy łączą idee proste, które obdarzają wspólną nazwą, odnoszącą się do cnót lub przywar, natomiast pojęcie drugich zdobywamy, gdy wychodzimy od reguł ustanowionych nam przez jakąś moc wyższą.

11. Ponieważ jednak nie możemy osiągnąć wiedzy o owych regułach, (1) nie wiedząc, kto jest prawodawcą całej ludzkości, obdarzonym mocą i wolą nagradzania oraz karania, a także (2) nie wskazując, w jaki sposób ogłosił on swą wolę i prawo, muszę obecnie zadowolić się założeniem istnienia takiej reguły, dopóki w dogodnym miejscu o tym nie powiem, tzn. o Bogu i prawie natury. Wspomnę teraz jedynie o tym, co konieczne do przedsięwziętego obecnie celu, a mianowicie, że (1) owa reguła naszego postępowania, ustanowiona dla nas przez prawodawcę, wiąże się ze wspomnianymi powyżej prostymi ideami i do nich się ogranicza, przykładem jest reguła „miłuj bliźniego swego jak siebie samego"; że (2) ponieważ owo prawo zakłada relację, którą znamy bądź sądzimy, że znamy, pomiędzy naszymi postępkami a tą regułą, to jest zgodność lub niezgodność z nią wszystkiego, co czynimy, jest ono nam znane równie łatwo i wyraźnie, jak każdy inny stosunek; że (3) do idei moralnych dochodzimy w taki sam sposób jak do innych, tak samo jak one, idee te są jedynie zbiorem idei prostych. Musimy tylko zwrócić szczególną uwagę na specyficzną cechę postępków moralnych, która sprawia, że należy je rozważać dwojako: (1) są one określone w sposób konkretny (wyrozumiałość, skromność, oszczędność, wesołość itd.), w związku z czym są one jedynie modi, to jest działaniami, na które składa się dokładnie określony zbiór idei prostych, jednak to nie z tego powodu określa się je jako dobre bądź złe, cnotliwe bądź występne v. g. ${ }^{6}(2)$. O ile odsyłają one do jakiegoś prawa, z którym są zgodne lub nie, wówczas dobre bądź złe, cnotliwe bądź

\footnotetext{
${ }^{6}$ Obecny w rękopisie dopisek „v. g.” pozostaje niejasny i jest pozostawiony bez komentarza w wydaniu krytycznym, będącym podstawą niniejszego tłumaczenia.
} 


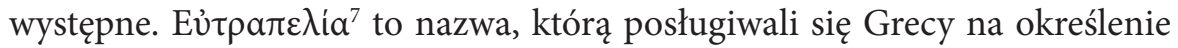
pewnego szczególnego rodzaju postępowania, tj. zbioru połączonych z sobą idei prostych, ale czy ów zbiór prostych idei zwany ev̉ występkiem, można wiedzieć jedynie wówczas, gdy odniesie się go do zasady, która określa, co jest cnotą, a co przywarą, określenie zaś zgodności z pewną regułą stosuje się właśnie do uczynków. W pierwszym przypadku chodzi jedynie o pewien zbiór idei prostych, a więc o pewną pozytywną ideę złożoną, $\mathrm{w}$ drugim natomiast o jej stosunek do pewnego prawa czy zasady, i zależnie od tego, czy pozostaje ona z nimi w zgodzie lub nie, jest ona cnotą bądź występkiem. Tak więc zarówno wykształcenie i pobożność, ucztowanie i obżarstwo, jako modi, są jedynie pewnymi złożonymi ideami, którym nadano pojedyncze nazwy; kiedy jednak rozważa się je jako cnoty, przywary i reguły, którym podlega życie, niosące ze sobą pewien obowiązek, wówczas odnoszą się do pewnego prawa, w związku z czym należy je uznać za rodzaj stosunku'.

12. Po to zatem, aby oprzeć moralność na właściwym gruncie i takich podstawach, które mogą nieść ze sobą pewien obowiązek, musimy w pierwszej kolejności udowodnić istnienie prawa, co wymaga założenia istnienia prawodawcy, który ma władzę i prawo rządzić, a także posiada moc nagradzania i karania w zgodzie z treścią ustalonego przez siebie prawa. Owym twórcą najwyższego prawa, który ustanowił reguły i ograniczenia ludzkich działań, jest Bóg, Stwórca ludzi, którego istnienie właśnie udowodniliśmy. Następną zatem rzeczą, jaką należy ukazać, jest istnienie pewnych reguł, pewnych nakazów, którym za sprawą Jego woli wszyscy ludzie powinni podporządkować swe postępki, a także to, że owa wola została w wystarczający sposób obwieszczona wszystkim ludziom.

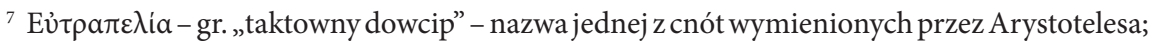
omawia on ją w Etyce nikomachejskiej 1127b-1128a. Fakt, że Locke nie przybliża czytelnikowi znaczenia tego pojęcia, może świadczyć o ugruntowaniu tego pierwotnego greckiego terminu w ówczesnym słowniku filozoficznym, pomimo rozpowszechnienia za Tomaszem z Akwinu zlatynizowanej formy zapisu eutrapelia oraz jej łacińskich odpowiedników: iucunditas (dowcipność) czy bona conversatio (wynajdywanie towarzyskich rozrywek). Zob. Święty Tomasz z Akwinu, Suma teologiczna, przeł. S. Bełch, London 1963, t. II-II, q. 168, a. 2, s. 323.

${ }^{8} \mathrm{~W}$ tym miejscu znajduje się skreślony początek zdania otwierający nowy akapit: „To, co w danej chwili stanowi dla umysłu większe dobro, determinuje jego wybór".
} 


\section{Etyka (Ethica) ${ }^{9}$}

Tym, co może pociągać istotę rozumną i być przyczyną jej działań, może być jedynie dobro. Dobrem tym jest jedynie przyjemność, większa przyjemność lub też środki do niej wiodące. Wszystkie przyjemności są sprawą umysłu, nie zaś ciała, niektóre jednak wymagają poruszeń ciała, niektóre jedynie rozmyślań i zadowolenia umysłu w niezależności od ciała, odrębnych i niezależnych od jakichkolwiek poruszeń czy pobudzeń ciała. Te drugie są zarówno większe, jak i trwalsze niż pierwsze. Pierwsze z nich skrótowo będziemy nazywać przyjemnościami zmysłowymi, drugie zaś przyjemnościami duszy; jedne - przyjemnościami materialnymi, drugie - niematerialnymi. Przyjemności zmysłowe nie trwają dłużej niż czas, w jakim przedmiot oddziałuje na zmysły i wypełniają jedynie drobną część życia najbardziej nawet oddanego zmysłom człowieka. Przyjemności smaku kończą się wraz z napełnieniem żołądka, a zaspokojony apetyt nie znosi najbardziej nawet wykwintnych potraw. Perfumy męczą człowieka już po krótkiej chwili albo też przestaje on je czuć. Niewielu na tyle zachwyca się muzyką, że gdy do niej przywyknie, wciąż nie przeszkadza im ona, a przynajmniej nie woleliby pogrążyć się w rozmowie z przyjacielem, co każdy może zauważyć u siebie samego bądź u innych. I chociaż wzrok zaznajamia nas z największą liczbą rzeczy i jest najczęściej używanym ze zmysłów, to jednak przyjemność, którą nam daje, tkwi nie tyle $\mathrm{w}$ zachwycie przedmiotami, które rozpościerają się przed oczyma, ile w tym, co się z nimi łączy: wiedzy i możliwości posługiwania się rzeczami potrzebnymi dla naszego życia oraz w pożytku, jaki daje wzrok we wszystkich aspektach naszego życia. Tak więc można powiedzieć, że wzięte razem, wszelkie przyjemności zmysłowe, także i te, o których

\footnotetext{
${ }^{9} \mathrm{~W}$ tytule tej części Locke odwołuje się do klasycznego łacińskiego określenia nauki o dobru: ethica, stosowanego m.in. do tłumaczenia tytułów dzieł Arystotelesa, chociaż w całym tekście posługuje się raczej terminem morality i morals. Ma ono tu podobne znaczenie jak u Kartezjusza, jako określenie (jeszcze scholastycznie) rozumianej dziedziny filozofii, o której Descartes pisze z niechęcią: „Autor niechętnie pisze na tematy etyczne [Auctor non libenter scribit ethica...], ale zmuszony był z powodu bakałarzy i im podobnych dopisać te reguły, bo w przeciwnym razie mówiliby, że jest niedowiarkiem i pozbawionym religii i że ją chce obalić za pomocą swej metody", R. Descartes, Rozmowa z Burmanem, [w:] tenże, Medytacje pierwszej filozofii, t. 2, przeł. I. Dąmbska, PWN, Warszawa 1958, s. 345).
} 
skromność nie pozwala mi mówić otwarcie, nawet u najbardziej oddanego zmysłom człowieka nie są nieustannie doznawane i nie wypełniają mu nawet ćwierci czasu, a jeśli przyjrzelibyśmy się temu bliżej, być może odkrylibyśmy, że wypełniają o wiele mniej, skoro jego ciało leży bezczynnie, nie odczuwając żadnej przyjemności. Być może jest i tak, że chociaż doznanie cielesne trwa tak krótko, to radość i przyjemność są dłuższe, stanowiąc wspaniałą rozrywkę. Zadowolenie trwa dłużej niż posiłek, który je daje, rozpoczyna się ono wcześniej i trwa, gdy ten się już skończył. Niechby i tak było, oznacza to bowiem, że nawet w przyjemnościach materialnych i zmysłowych, największą rolę odgrywa namysł i gdy zmysły już milczą, umysł w myślach wciąż odczuwa przyjemność, w której zmysły nie mają już swego udziału. Wyciągam $z$ tego wniosek, że nawet u najbardziej oddanych zmysłom ludzi umysł, a nie ciało, odgrywa największą rolę w szczęściu, w przeciwnym razie ich życie jest szczęścia pozbawione.

Jeśli zatem naszym zajęciem i celem jest szczęście, jasne jest, że aby je osiągnąć, musimy kochać naszych bliźnich jak siebie samego, gdyż w ten sposób zwiększamy i zapewniamy sobie przyjemność, całe bowiem dobro, które czynimy, wraca do nas, dając nam niesłabnącą i nieprzerwaną przyjemność. Każdy, kto uratował głodującemu życie, oddając mu swój posiłek, uczynił z niego większego przyjaciela niż wszyscy, których kocha, osiągnął o wiele większą z tego przyjemność niż ktoś, kto taki posiłek zjadłby samemu. Ta druga przyjemność skończyła się, gdy tylko przestał jeść i zakończył posiłek, ten jednak, kto posiłek ten oddał innemu, może ucztować zawsze, gdy o nim pomyśli.

Przyjemności umysłu są wspanialsze i trwają najdłużej. Czy jest ktoś, kto na tyle przypomina zwierzę, że nie porzuciłby zmysłowej przyjemności, gdyby musiał ratować kochane przez siebie dziecko, który to ratunek stanowi przecież przyjemność umysłu tak daleką od jakiejkolwiek przyjemności zmysłowej? Kochaj świat tak samo jak swe własne dziecko i samego siebie, uczyń swą miłość tak wszechobecną, a wówczas niebiosa przestaną być tak odległe od ziemi.

Szczęście wiąże się przeto z naszym miłowaniem bliźnich i spełnianiem naszych obowiązków, z aktami miłości i dobroczynności, choć ktoś mógłby temu zaprzeczyć, ponieważ nie wszyscy przestrzegają owej reguły powszechnej miłości i dobroczynności. Ktoś taki zakłada konieczność przyszłego życia (w którym Bóg rozdziela tych, którzy postępowali dobrze i cierpieli przez to, oraz tych, którzy czynili zło i wiedli szczęśliwe życie), a przez to tym bardziej 
umacnia moralność, widząc konieczność Bożej sprawiedliwości oraz nagród i kar, dzięki którym dobrzy zwyciężą, a występni przegrają.

Przekład i opracowanie: Adam Grzeliński

Uniwersytet Mikołaja Kopernika, Toruń, Polska e-mail: Adam.Grzelinski@umk.pl

Marcin T. Zdrenka

Uniwersytet Mikołaja Kopernika, Toruń, Polska e-mail: Marcin.Zdrenka@umk.pl 